\title{
Housing Wealth Decisions in Old Age: Sale and Reversion
}

\author{
JOAN COSTA-FONT*, JOAN GIL** \& OSCAR MASCARILLA** \\ *London School of Economics, London, UK, and CAEPS, Barcelona, Spain, **Universitat de, B $\bar{\equiv}$ na, Spain,
and CAEPS, Bercelona, Spain
}

(Received June 2007; revised October 2009)

\begin{abstract}
Population ageing brings new challenges to long-term household economic decisions. In the event of old-age dependency, housing assets become a key self-insurance device. However, little empirical evidence has been reported regarding an individual's expectations of having to use their housing wealth for such a purpose. This paper draws upon two complementary data sources to empirically examine: (1) the influence of housing assets on an individual's willingness-to-sell (WTS) their dwelling for care purposes, and (2) the willingness to take out a reverse mortgage contract loan in the event of old-age dependency. The paper's findings suggest that homeowners' WTS in old age is unaffected by their income or housing assets and is, rather, determined by socio-environmental housing characteristics and the individual's health and personal needs. Conversely, the study finds that the uptake of home reversion loans is largely dependent on income or education, but not on a household's housing assets.
\end{abstract}

Key WoRDs: Housing wealth, homeownership, reverse mortgage, old-age dependency, asset accumulation, savings in old age

\section{Introduction}

Differences in socio-economic status in old age mainly consist of differences in wealth. Indeed, Venti \& Wise (1991) reported that approximately 80 per cent of the wealth of older households in the USA was stored in the form of housing equity, which could be sold in the event of need. ${ }^{1}$ However, the effect of wealth in the form of housing assets on an individual's behaviour during old age is largely unknown. Some studies have suggested that the 1990s burst in the housing price bubble in the West overwhelmingly benefited older households and had a more detrimental impact on their younger counterparts (Gale \& Pence, 2006). This explains the commonly held view of the elderly as being 'income-poor and housing-rich' (Costa-Font et al., 2009; Hancock, 1998; Kee-Lee et al., 2006; Sodha, 2005). Thus, housing assets, albeit not always specifically allocated to this purpose, might act as an implicit self-insurance device. Yet, when old age needs arise, individuals might

Correspondence Address: Joan Costa Font, London School of Economics, Cowdray House, Houghton Street, London, WC2A 2AE. Email: j.costa-font@1se.ac.uk 
fail to allocate housing assets efficiently due to market imperfections and liquidity constraints, together with potential conflicts with other underlying goals. Therefore, individual housing decisions can be viewed as resulting from a trade-off between tangible house market values with non-tangible environmental benefits and other life objectives such as 'ageing in place'.

Homeownership (a requirement for self-insurance) has been found to be more common in households whose members are below 70 years of age (Jones, 1997), suggesting that some elderly citizens sell their homes after a certain age, either to meet the needs of old age or to transfer assets to their offspring while they are alive, presumably in exchange for care (Becker, 1981). However, whether this is the desired and most efficient option for the elderly is subject to debate and calls for empirical evidence. Figure 1 shows expectations with regard to the financing of care on reaching old age. Interestingly, these data reveal that Spain, together with Portugal, is the EU-15 country that reports the greatest share of self-insured people expecting to cover long-term care expenditures.

Growing financial sophistication has seen the introduction of specific instruments (e.g. home reversion loans), which have been developed as alternative mechanisms to property sale. The uptake of home reversion loans became significant, although a decline was observed after 2007, as the wealth of Spanish households rose sharply as a result of marked increases in housing prices. Furthermore, the proportion of owner-occupied homes in Spain is one of the highest in the developed world. At the same time, in recent years there have been considerable changes in the mortgage market particularly, while the range of products available has broadened. Products such as reverse mortgages already exist on the Spanish market, and are particularly appropriate for the elderly and relatively less affluent homeowners. Indeed, reversion means that the mortgagor receives a supplementary income through monthly payments, which may be for life or for a stipulated period in exchange for the eventual hand-over of the home to the financial

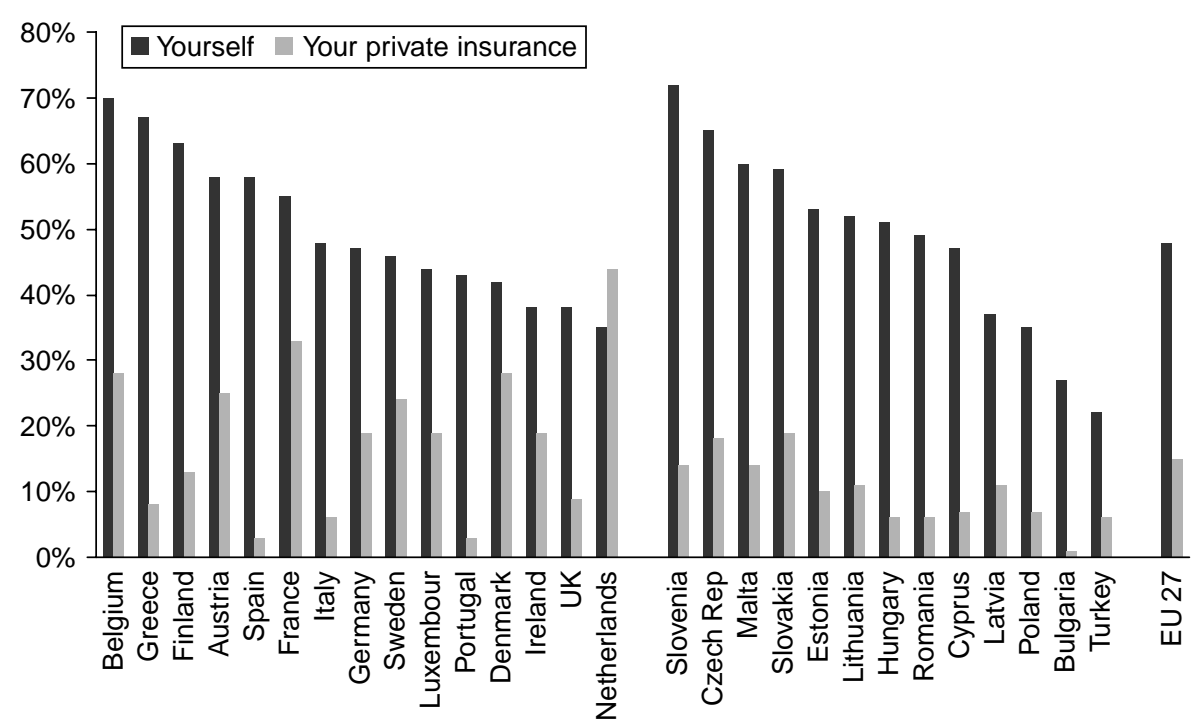

Figure 1. Expectations for the financing of care on reaching old age in the European Union. Source: Eurobarometer (2006). 
institution granting the transaction. Ownership of the home remains unmodified and may even pass to the heirs once the debt has been cancelled. Hence, additional instruments to help the elderly face the self-insurance expenditure of old age are being developed, although evidence as to how individuals react to them is as yet under-researched.

The main aim of this paper is to examine whether income and housing equity, among a sample of homeowners, exert any influence on the willingness-to-sell (WTS) their dwelling to meet the expenses of old age. This question is examined after controlling for self-reported housing satisfaction (SRHS), which has been found to be a predictor of an individual's housing mobility (Diaz \& Stoyanova, 2008), although no evidence to date has confirmed that this is also true for elderly individuals who are in need of care, despite its considerable policy impact. A second aim of this paper, therefore, is to explore the willingness on the part of these individuals to take out a reverse mortgage loan in the event of old-age dependency. Our results suggest that housing wealth is not sufficient to explain both the willingness on the part of the elderly to sell their house and their willingness to take out reverse mortgage loans in their old age. The two decisions seem to be explained instead by the respondent's age, yet whilst the willingness-to-sell is explained by housing satisfaction; the uptake of reverse mortgages is driven by income and education.

The structure of the paper is as follows. The next section discusses the issue of homeownership in old age, while the third section presents the functioning of reverse mortgages. The following section describes the two databases employed in the study and reports the empirical models used to examine both the willingness-to-sell and the willingness to take out reverse mortgages. The fifth section reports the results and the paper ends with the concluding section.

\section{Homeownership and Self-Insurance}

Homeownership is a specific type of tenancy whereby, in addition to other characteristics common to any tenure, individuals develop a specific identity (Rohe \& Stegman, 1996) and gain financial security, as housing is an asset in which savings can be accumulated. ${ }^{2}$ Although there is some debate as to whether individuals exhibit a systematic preference for homeownership (Forrest et al., 1990), it is generally acknowledged that homeownership generates personal capital. However, the amount of capital varies according to the size of the mortgage payments (Ford et al., 2001), the neighbourhood and the income group to which the individual belongs. Furthermore, housing equity increases with a rise in house values, as long as the family remains in the same home (Venti \& Wise, 1989). In most Western countries, the vast majority of personal savings for old age, the so-called 'compulsory savings', take the form of housing equity, which accounts for the fact that the elderly are often regarded as having 'low income and a disproportionately high wealth' (Hancock, 1998). The reasons for this are, in part, attributable to the fact that housing wealth acts as a self-insurance device for finance consumption in old age. ${ }^{3}$ Some studies report that in the USA the vast majority of personal savings take the form of housing equity (Venti \& Wise, 1991) and this is also the case for Spain.

Southern European countries present a relatively large proportion of owner-occupation, which is often linked to an apparent trade-off between homeownership and expansion in welfare services, in particular pension systems (Castles, 1997). Indeed, fiscal policies in countries such as Spain have provided incentives for homeownership (e.g. tax relief on mortgage payments), while the promotion of social housing has been very limited 
(Castles \& Ferrera, 1996). However, although housing can act as a self-insurance mechanism in old age, liquidity problems arise when long-term care (LTC) has to be paid for out of individual wealth. Yet, in countries such as Spain where the family still plays a key role (unlike in other central and northern European countries where financial independence is a key value) housing wealth is the main asset protecting the family in those areas where social protection is not universal, such as LTC services (Costa-Font et al., 2006).

The ageing process that is taking place in Western countries has given rise to a need for new means of funding LTC for elderly disabled people. The individual's home has been defined as a place that engenders social, psychological and cultural security (Lewin, 2001), and can be seen as the locus of personal control and identity (Saunders, 1990). Although the meaning of 'home' is transitory (Gilman, 2002) and changes with an individual's age and the number of household members, an elderly person's attachment to their home is connected to personal self-esteem and security, especially if they suffer from a specific disability, which is only subject to small public sector welfare benefit entitlement in most European countries. At the same time, the ageing process raises new concerns regarding elderly people who suffer from health-related disabilities. Benefits are awarded to people with severe cognitive or mental disabilities, those who require help in certain activities of daily living (ADL) such as eating, using the toilet, dressing, bathing and getting in and out of bed. Housing satisfaction also has a potential impact on the health of individuals. Such satisfaction is influenced by psychosocial housing characteristics such as perceived safety, structural quality and the household size (Hwang et al., 1999).

The capacity of individuals to pay for LTC services in old age is a key housing policy question, given that access to publicly funded care is subject to means testing. However, there are alternative (self-financing) sources of funding for both care and incomereplacement needs in old age that complement public funding schemes. Approximately 86 per cent of the Spanish population owns their own home (European Mortgage Federation, 2004 ${ }^{4}$ ) - a figure that is higher than in any other European country-whilst housing accounts for 28 per cent of total expenditure, also the highest proportion in Europe. Among the elderly, 74 per cent are homeowners (although only 7 per cent are still paying their mortgage), 16 per cent are tenants and 3 per cent use other means of accessing housing services (INE, 2004). Therefore, housing assets are a source of interaction between broad social policy objectives to avoid social exclusion in old age and housing policy that leads to homeownership. Having a place to call 'home' is important to elderly people, who would otherwise be placed in a nursing home or residence. Housing is a place for 'self-development', in which individuality and autonomy can be attained as well as a relational space (Dorvil et al., 2005).

\section{Home Reversion: Patterns and Evidence}

Recent trends in Spanish housing prices have had a significant impact on both middle-aged and elderly homeowners (Carreras et al., 2004), giving rise to a paradoxical situation in which a significant share of the population is 'asset wealthy and income poor' (Hancock, 1998, p. 2). This is particularly the case of sectors of the population for whom wealth accumulation results primarily from homeownership. This profile, as discussed widely elsewhere, would probably benefit from the development of home reversion instruments to finance the needs, primarily those of personal care, of old age (Leviton, 2001). Indeed, home reversion constitutes a relatively efficient alternative to self-insurance instruments and, in certain 
circumstances, could even be a better option than one in which individual risks are pooled together. The obvious pitfall of the latter, although rationally it might appear to be more efficient, is that it relies on the ability to foresee future financial needs by paying premiums systematically and planning ahead accordingly. Insurance-based products, such as long-term care insurance, have a long tradition in both the US and the UK. ${ }^{5}$ However, rising house prices, as will be argued, have tended to favour self-insurance options. Yet, whether housing wealth constitutes an adequate mechanism for the self- insurance of future personal care is an empirical question subject to empirical scrutiny.

In this context, reverse mortgages appear as likely instruments that can help older families convert home equity into cash, but with households living longer, the risk associated with many home equity products is that the homeowner will outlive the annuity and be forced to move at an advanced age. Broadly, it may be stated that the wealth effect arising from the real estate market is more important in those countries where mortgage facilities make it easy to obtain liquidity.

In general, a reverse mortgage is a special home loan that allows a homeowner to cash in their property while they continue to live in the house. In this way, the equity built up after years of home mortgage payments can be paid back to the individual. The homeowner does not need to repay the principal as long as he/she (or the spouse) continues to live in the house. On their death, the heirs only have to repay the sum of the loan received. The amount of money borrowed from a reverse mortgage depends on the age of the borrower, the appraised value of the home and the current interest rate and can be paid in a single lump sum or as a regular monthly payment. To be eligible for a reverse mortgage, the borrower must own his/her home and preferably be 70 years of age or older ( 62 or older in the USA). Since the loan has a limited duration (usually 10-15 years), financial institutions usually recommend that clients contract the reverse mortgage jointly with an annuity (Chian \& Tsui, 2005). In 1989, the US Government established the Home Equity Conversion Mortgage (HECM) insurance programme which created an insurance model to cover the risks of reverse mortgages, provided flexible payment options to consumers, established a consumer counselling programme, and developed model consumer disclosures and laid the foundation for funding the loans by investors.

\section{Data and Empirical Strategy}

\section{The Data}

This study combined evidence from two databases as follows:

A. Database one. The study uses data from a unique survey published and made available by the Institute Edad \& Vida, a non-profit entity devoted to the study of old-age dependency and ageing in general. This institution commissioned a study to examine individual attitudes in the event of old-age dependency and gave the authors the opportunity to participate in its design. To that end, a survey was conducted between September and November 2003 based on a representative Spanish population sample of 729 individuals aged 55 and over, using computer-assisted telephone interviewing (CATI system) to obtain a random sample. The resulting data are of standard quality and a comparative analysis with other publicly commissioned surveys did not demonstrate any significant differences. ${ }^{6}$ 
The main advantage of employing a self-designed survey was that it provided the opportunity to investigate questions that are not usually raised in representative surveys. Indeed, it was possible to measure attitudes and preferences of elderly people on a variety of issues, including housing satisfaction. Health status was gauged using continuous measures. The survey included a list of disabilities and dependencies and contained the characteristics of each individual's dwelling. This enabled house values to be calculated from the estimated value per square metre for the Autonomous Region at the time of the interview (see Table A1 in the Appendix). Finally, it is worth mentioning that the survey contained questions regarding individual preferences for ageing-in-place and the WTS the dwelling in case of dependency needs, in order to provide an insight into changes in housing preferences over time. ${ }^{7}$

A description of this first database is presented in Table A2 in the Appendix. The mean age was 67.6 years, with 28 per cent of the sample in the 55-59 age range, while 11 per cent were over 80 years old. The socio-economic characteristics of the respondents were similar to those published by IMSERSO (2002). Approximately 85 per cent of the individuals interviewed lived in flats and the rest in houses, 84.3 per cent stated that they owned their dwelling and 3.4 per cent said they lived in someone else's property, while only 12.1 per cent lived in a rented flat. When asked about their future concerns, housing hardly ever emerged as an issue ( 0.7 per cent). Instead, health ( 79 per cent) and family ( 19 per cent) were reported as being priorities. This can be attributed to various factors, including the fact that most of them had already paid for their home. Although 62.5 per cent reported two activity-daily-living limitations from the nine considered, only 32.2 per cent received any form of help: 14.7 per cent from family, 13.6 per cent from their partner and 3.4 per cent from a professional caregiver. In addition, 55.6 per cent of respondents declared they depended on their income pension and 21 per cent reported living on their income. Interestingly, 58 per cent were not able to save the income they received.

The mean size of individual dwellings was 102.3 square metres, with 3.3 bedrooms (see Table A1 in the Appendix for variations in housing prices in 2003). ${ }^{8}$ When asked about their willingness to change dwelling, 55 per cent of those interviewed asserted they would not change and the mean housing satisfaction index was 7.91. ${ }^{9}$ However, whilst this figure was 8.1 for homeowners, it was only 6.9 for renters $(p<0.05)$. Only 20 per cent of the sample was made up of individuals living alone. In the event of having to face the needs of old-age dependency, 78.1 per cent said they would prefer to live at home, 16.3 per cent in a nursing home, and 5.6 per cent in a relative's home. The last group had received less formal education and was mostly over 75 years of age ${ }^{10}$ However, 51.7 per cent said they would be unwilling to sell their homes in order to gain access to long-term care, whilst 26 per cent said they would be willing to do so.

B. Database two. As with the willingness-to-sell one's own home, the non-existence of data in Spain to examine the willingness to take out a reverse mortgage meant that here again a dataset had to be constructed. A random telephone survey (CATI method) of 500 individuals was undertaken (margin of error of \pm 5 per cent) to collect information on reverse mortgages for a sample: (1) of persons aged 50 years and over; (2) of persons who were the owners of their main residence; and, (3) at a nationwide scale, but also by Nielsen areas (Costa-Font et al., 2007). ${ }^{11}$ A preliminary version of the questionnaire was submitted to scrutiny for a similar group of elderly members of the population in Madrid and in Barcelona, with the purpose of improving the clarity of the questions. In some instances 
the data are comparable to datasets used by Redfoot et al. (2007) in their exhaustive analysis of reverse mortgages in the USA.

There exists an extensive international literature aimed at measuring the potential beneficiaries of reverse mortgages and the ways in which such products might contribute to an increased level of consumption or supplement the incomes of poor or low-income homeowners, ${ }^{12}$ although the conclusions are somewhat mixed (Ong, 1998). The present study chose to deviate from the literature and, given the nature of the data, it was decided to focus the analysis on the willingness to contract reverse mortgages together with the degree of familiarity with these loans. As far as is known, this is the first empirical exploration of the determinants of contracting home equity conversion loans in a bivariate setting.

\section{The Institutional Setting}

Approximately 17 per cent of the Spanish population was over 65 years of age in 2005 and it is estimated that this proportion will reach 31 per cent by the year 2050, which means that this age group is set to increase at a much faster rate than the rest of the population (IMSERSO, 2006). The elderly constitute a heterogeneous group, subject to significant change, and while ageing implies greater exposure to disability, the traditional view that the elderly are a frail and economically weak group is challenged by evidence suggesting that an increasing number are in fact healthy and relatively affluent.

Social position in old age is affected by various considerations: age (socio-economic status declines with age); Autonomous Region (differences exist in purchasing power across Spanish regions); and environmental factors (IMSERSO, 2006). Less than 1 per cent of individuals aged over 70 are in the labour market and in the case of women this figure is just 0.5 per cent. Some scholars, therefore, estimate a significant reduction in the saving rate due to the ageing process. Housing assets are the family's main assets: 87 per cent of the elderly are homeowners and approximately 88 per cent live in their own homes, while 12 per cent live with their children. Of the more than 6000 residential-care centres in 2006, only 1060 (17.5 per cent) were publicly owned and the average number of beds per 100 elderly people was four, well below EU standards (IMSERSO, 2006). ${ }^{13}$

Elderly people are less likely to be paying a mortgage, as mortgages are usually for a period of between 20 and 30 years. Therefore, the effects of housing tenure can be more clearly observed. Unlike this study, previous research has examined exclusively the effect of housing tenure, without taking into account the effect of house value. However, this study's estimation of housing value is only approximate, as it is based on the assumption that the price of each dwelling is a linear function of the average value per square-metre in each region. The costs of long-term care consume a large proportion of individual wealth and can become ruinous. Institutionalisation generally has devastating financial effects on old people and their families. Therefore, welfare programmes tend to overcome individual difficulties by meeting the needs of impoverished disabled people. However, welfare benefits are usually means-tested, although this system has been criticised for allowing 'welfare fraud', as middle-class people may transfer their assets to meet public-sector eligibility requirements.

\section{The Decision to Sell One's Dwelling in Old Age}

As this study sought to investigate the decision to sell the home before it took place, two expected utility functions were specified depending on whether individuals sell their 
properties or not in the event of their requiring LTC, as follows: if people do not sell their property, then they have to face the costs of LTC provision, so that non-housing wealth $\left(y_{t}\right)$ would be expected to diminish as a result of the costs of paying for care $\left(L_{t}\right)$ with a probability of $(\varphi)$. On the other hand, in the case of old-age dependency, the well-being function would presumably still be increasing in its arguments and concave, although behaviourally different from cases in which no LTC is required, so that $U^{\prime}(\cdot) \geq V^{\prime}(\cdot)$. As a result, the following function was obtained in cases of old-age dependency when the property is not sold:

$$
E U^{n s}=\varphi V\left(y_{i}-L_{i}, h_{i}, x_{i}, z_{i}\right)+(1-\varphi) U\left(y_{i}, h_{i}, x_{i}, z_{i}\right)
$$

Alternatively, if people are prepared to sell their home to cover care-related expenses, this would impact individual wealth by $W_{t}$ as follows:

$$
E U^{s}=\varphi V\left(y_{i}+W_{i}-L_{i}, h_{i}, x_{i}, z_{i}\right)+(1-\varphi) U\left(y_{i},+W, h_{i}, x_{i}, z_{i}\right)
$$

Thus, people will sell their dwelling if $E U^{s} \geq E U^{n s}$. Having determined housing satisfaction levels, the next step was to ascertain whether homeowners (who made up the majority of the sample) were willing to change dwelling as a result of the lack of housing satisfaction, among other reasons. To control for possible sample selection of homeownership, the inverse-Mills lambda variable, based on a first-stage regression, was added, although it was found not to be significant. This suggested that sample selection was absent and, as a result, the coefficient was not reported. Finally, the willingness-to-sell equation was specified as a continuous 'latent variable' model (WTS *) as follows:

$$
W T S_{i}^{*}=\gamma_{0} S R H S_{i}+\gamma_{1} W_{i}+\gamma_{2} h_{i}+\gamma_{3} q_{i}+\gamma_{4} y_{i}+\gamma_{5} z_{i}+\varepsilon_{i}
$$

where $S R H S_{i}$ stands for self-reported housing satisfaction; $h_{i}$ measures need-related conditions; $q_{i}$ represents homeowner characteristics, $y_{i}$ indicates individual's income and $W_{i}$ individual's wealth, while individual characteristics are represented by $z_{i}$. The random error term $\varepsilon$ is assumed to be distributed as a normal function with zero mean and unitary variance. As the WTS is observed through a binary variable ( 1 if the individual is willing to sell the own house/flat, 0 otherwise), the model was estimated using a probit regression model. An endogeneity test of SRHS was performed to determine whether an instrumental variable regression approach was needed. ${ }^{14}$

\section{Ageing in Place and Willingness to Take Out a Reverse Mortgage Loan}

Alternatively, if homeowner characteristics and satisfaction, such as 'ageing in place', are high enough $\left(\gamma_{3}, \gamma_{0}>>0\right)$ and a third option is available, home reversion might be a viable alternative. The willingness to purchase this instrument is defined by an analogous estimation in the same way as the estimation in (3). Hence, to examine the factors underpinning the willingness to take out a reverse mortgage on the part of those interviewees who claimed they knew about such products, a bivariate probit regression model was estimated. This approach made it possible to estimate the probability of contracting reverse mortgages together with the probability of being familiar with such conversion loans. The latent variable $W T C^{*}$ is defined as the willingness or inclination to contract a reverse mortgage and the latent variable $F A M^{*}$ measures familiarity with such conversion products. Because these variables are not directly observable, it is 
specified that each latent variable is a linear function of a set of explanatory variables,

$$
\begin{gathered}
W T C_{i}^{*}=\beta_{0} z_{i}+\beta_{1} y_{i}+\beta_{2} W_{i}+\beta_{3} e_{i}+\beta_{4} l_{i}+\varepsilon_{i, 1} \\
F A M_{i}^{*}=\delta_{0} z_{i}+\delta_{1} y_{i}+\delta_{2} W_{i}+\delta_{3} e_{i}+\delta_{4} l_{i}+\varepsilon_{i, 2}
\end{gathered}
$$

where $\varepsilon_{1}$ and $\varepsilon_{2}$ are the random error terms of each equation and are jointly normally distributed with means zero, variances one and correlation $\rho=\operatorname{cov}\left(\varepsilon_{1}, \varepsilon_{2}\right) .{ }^{15}$ By allowing for a correlation between the error terms in the two equations, it is recognised that there may be unobservable characteristics of individuals influencing whether they are willing to contract and their self-assessed knowledge. Note that the bivariate regression model collapses to two separate probit models when the correlation coefficient for the two error terms $\rho=0$. The set of parameters $(\beta, \delta)$ was estimated by means of maximum likelihood methods.

In line with some reports in the literature, it was assumed that contracting a reverse mortgage depended on a vector of personal characteristics $\left(z_{i}\right)$ such as gender, age and region of residence defined in the dataset by Nielsen areas (Table A3 in the Appendix). Moreover, as reverse mortgages meet the particular needs of elderly homeowners who are 'cash poor but housing rich', two additional covariates were included: a measure of individual income $\left(y_{i}\right)$ computed as the logarithm of the pension benefit and a proxy of home value $\left(W_{i}\right)$ calculated by its expected selling price of a midpoint interval, expressed in $\log$ terms. ${ }^{16}$ Finally, it was assumed that the inclination to contract a reverse mortgage was also influenced by both the level of education $\left(e_{i}\right)$ and the labour status $\left(l_{i}\right)$, which aimed at measuring the degree of awareness and interest regarding general financial instruments for funding old age. Note that the same set of independent variables was used to explain the probability of knowing or being familiar with reverse mortgages. ${ }^{17}$ Table A3 shows the definitions and descriptive statistics of each covariate.

\section{Hypothesis Testing}

On the basis of the previous theoretical framework and preliminary evidence is possible to formulate the following hypothesis:

Hypothesis 1. The hypothetical willingness-to-sell one's home (WTS) is explained by income and wealth, which reflect a socio-economic vector together with the degree of satisfaction for one's dwelling. The latter covers the (primarily environmental) embedding effects that cause individuals to become attached to their dwelling.

Hypothesis 2. The willingness to contract a reverse mortgage (WTC) is inversely related to individual age and income and positively related to individual wealth, and unrelated to income and wealth.

\section{Results}

Willingness-to-sell

Table 1 presents basic descriptive data, at the regional level, regarding the percentage of homeowners, the percentage expressing willingness-to-sell their dwelling in the 
event of old-age dependency (i.e., to by an adequate house/flat or to pay for long-term care services), individual self-reporting housing satisfaction (SRHS), the percentage of respondents who would prefer to live in a nursing home and, finally, the percentage who would prefer to 'age in place' (to go on living in their dwelling) in case of perceiving difficulties in some activities of daily living after certain age. In the bottom part of Table 1, partial correlation coefficients for each of the variables examined are provided.

Between 80 and 90 per cent of the population were homeowners, with the exception of those in the Autonomous Region of Castile-Leon, where they accounted for two-thirds of the population. This suggests that there is some potential for using people's own homes as a means of financing ageing-related expenses. Individuals WTS to pay for the expenses associated with old-age dependency varied from 40 to 45 per cent in Navarre, La Rioja and Catalonia to 30 per cent in the Balearic Islands and Aragon, indicating that the inhabitants of the most affluent Autonomous Regions in Spain—with the exception of Madrid, the seat of the central government, which has a large share of civil servants-were more likely to be willing to sell their dwellings to finance old-age dependency services. Interestingly, WTS was only significant and negatively correlated with those who chose 'ageing in

Table 1. Exploratory regional analysis by Autonomous Region

\begin{tabular}{|c|c|c|c|c|c|}
\hline $\begin{array}{l}\text { Autonomous } \\
\text { Regions }\end{array}$ & Homeowners $(\%)$ & (\%) WTS & SRHS & $\begin{array}{l}\text { Preference stated } \\
\text { for nursing home } \\
(\%)\end{array}$ & $\begin{array}{l}\text { Preference stated } \\
\text { for 'Ageing in } \\
\text { place' }(\%)\end{array}$ \\
\hline Andalusia & 81.9 & 22.2 & 8.28 & 12.4 & 83.01 \\
\hline Aragon & 93.8 & 31.3 & 7.81 & 18.8 & 75.0 \\
\hline Asturias & 97.0 & 23.8 & 8.05 & 15.0 & 85.0 \\
\hline Balearic Islands & 73.7 & 31.6 & 7.95 & 15.8 & 78.95 \\
\hline The Canaries & 88.9 & 19.4 & 7.76 & 10.8 & 83.78 \\
\hline Cantabria & 100.0 & 25.0 & 8.67 & 25.0 & 66.67 \\
\hline Castile-Leon & 66.7 & 11.1 & 7.78 & 7.4 & 77.78 \\
\hline Castile-La Mancha & 97.0 & 20.0 & 9.40 & 14.3 & 85.71 \\
\hline Catalonia & 77.7 & 43.8 & 7.51 & 11.9 & 79.37 \\
\hline Valencia & 83.7 & 16.3 & 7.53 & 12.2 & 79.59 \\
\hline Extremadura & 87.0 & 26.1 & 8.17 & 30.4 & 65.22 \\
\hline Galicia & 93.3 & 26.7 & 6.93 & 13.3 & 86.67 \\
\hline Madrid & 88.3 & 20.2 & 7.93 & 26.4 & 70.91 \\
\hline Murcia & 88.0 & 36.0 & 7.88 & 20.0 & 76.0 \\
\hline Navarre & 97.0 & 45.5 & 7.91 & 40.0 & 40.0 \\
\hline Basque Country & 87.0 & 18.2 & 7.85 & 17.4 & 80.43 \\
\hline La Rioja & 85.7 & 42.9 & 7.71 & 14.3 & 71.43 \\
\hline \multicolumn{6}{|l|}{ Correlations } \\
\hline$\rho$ (Homeowners) & - & 0.12 & -0.19 & -0.15 & -0.08 \\
\hline$\rho$ (WTS) & 0.12 & - & -0.27 & 0.36 & $-0.49 * *$ \\
\hline$\rho$ (SRHS) & -0.19 & -0.27 & - & -0.18 & -0.05 \\
\hline$\rho$ (Nursing home) & -0.15 & 0.36 & 0.18 & - & $-0.87 *$ \\
\hline$\rho$ ('Ageing in place') & 0.08 & $-0.49 * *$ & -0.05 & $-0.87 *$ & - \\
\hline
\end{tabular}

Note: WTS means the willingness to sell the own house/flat in case of old-age dependency; SRHS means self-reporting housing satisfaction regarding the own dwelling. *significant at $1 \%$; **significant at $5 \%$. Source: Encuesta Edad \&Vida (2003). 
place' (-0.49). This suggests that individuals who were more likely to spend their old age in their dwelling valued their dwelling's characteristics highly and, as a result, they were less willing to switch to somewhere else. As Figure 2 reports, WTS one's home was highly age-dependent. It ranged between 25 to 35 per cent among those under the age of 70, but this percentage fell to between 10 to 15 per cent in older age groups. This can be explained by the advantages that a familiar environment provides to the older age group. However, in addition, older age groups have usually already found the best possible solution for financing the expenses caused by old-age dependency.

Probit estimates of the determinants of the WTS decision are presented in Table $2 .{ }^{18}$ One specification included SRHS as a covariate (Equation 1) while the other did not (Equation 2). According to the estimates of Equation (1), SRHS exerted a negative and statistically significant effect on WTS in the event of old-age dependency needs, providing evidence of an 'ageing in place' phenomenon. This means that the probability of expressing WTS is 4 per cent lower for a 1 per cent increase in the housing satisfaction index. This 'ageing in place' or the stated preference to remain at home may be attributable to the fact that greater housing satisfaction makes people less willing to sell and to identify other ways of paying for the costs of old age (e.g. home reversion loans). Therefore, as expected, SRHS constituted an important determinant of housing decisions in old age, arguably masking the influence of unobserved variables (Hypothesis 1). Housing characteristics were statistically significant, suggesting that people who lived in houses as compared to flats were 30 per cent more likely to express WTS; houses are relatively less suitable environments for people with old-age dependency difficulties. Furthermore, respondents who perceived their home as being large were about 30 per cent more likely to display WTS. Unexpectedly, socio-economic effects including education, income and wealth were not significant. There was some evidence of gender-related effects, suggesting that 'embedding' in the home was higher in men.

For comparative reasons, the effect of removing SRHS from the WTS decision was examined (equation 2) to control for the extent to which individuals are embedded in their

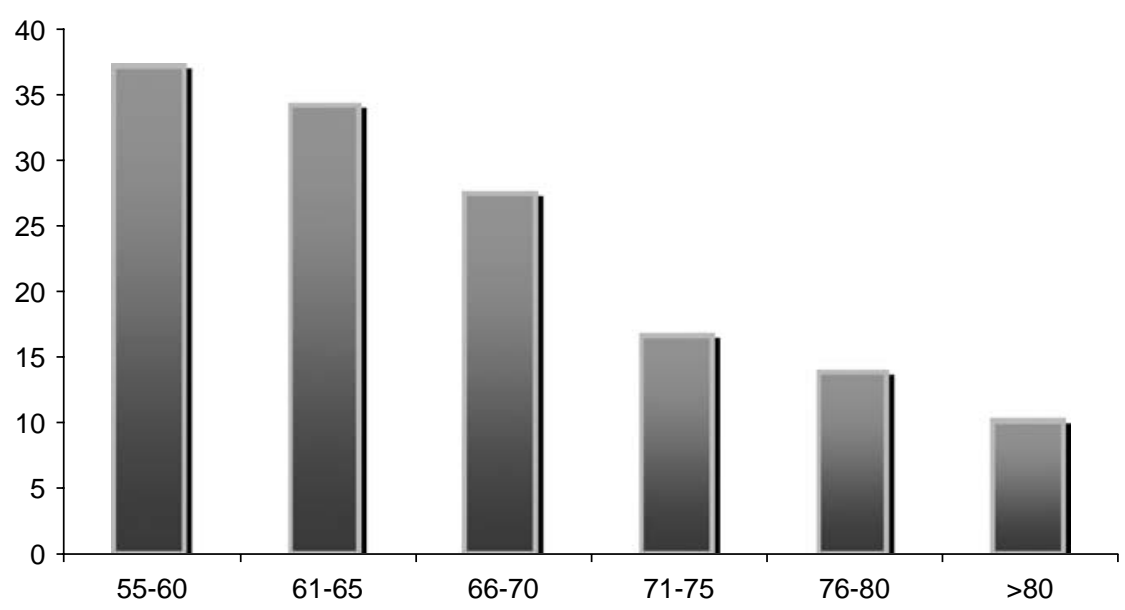

Figure 2. Willingness-to-sell (WTS) one's home to access suitable housing. Source: Encuesta Edad \&Vida (2003). 
Table 2. Determinants of willingness-to-sell (WTS)

\begin{tabular}{|c|c|c|c|c|c|c|}
\hline & \multicolumn{3}{|c|}{ Eq. (1) } & \multicolumn{3}{|c|}{ Eq. (2) } \\
\hline & M.E & s.e & t-value & M.E & s.e & $\mathrm{t}$-value \\
\hline Home value & -0.002 & 0.001 & -1.45 & 0.1904 & 0.1174 & 1.62 \\
\hline Income & -0.001 & 0.009 & -0.06 & 0.0565 & 0.1017 & 0.56 \\
\hline Savings & 0.001 & 0.070 & 0.01 & -0.001 & 0.001 & -1.00 \\
\hline Educ1 & 0.168 & 0.270 & 0.71 & $-7 \sqrt{\equiv}$ & 0.059 & -0.13 \\
\hline Educ2 & -0.153 & 0.071 & -1.62 & $-\overline{20+4}$ & 0.062 & -0.70 \\
\hline Educ3 & -0.046 & 0.080 & -0.57 & 0.289 & 0.285 & 1.01 \\
\hline Educ4 & -0.128 & 0.074 & -1.36 & $-\bar{\equiv}$ & 0.082 & -0.88 \\
\hline House & $0.293 *$ & 0.148 & 1.98 & F. 2023 & 0.115 & 1.75 \\
\hline Large size & $0.318 *$ & 0.151 & 2.00 & 0.1904 & 0.1175 & 1.62 \\
\hline Small size & 0.281 & 0.181 & 1.51 & 0.0565 & 0.1017 & 0.56 \\
\hline Gender & $-0.128 *$ & 0.061 & -2.10 & -0.0037 & 0.007 & -0.51 \\
\hline Age2 & 0.182 & 0.250 & 0.83 & $-0.131 *$ & 0.067 & -1.98 \\
\hline Age3 & 0.041 & 0.103 & 0.41 & 0.059 & 0.087 & 0.68 \\
\hline Age4 & 0.045 & 0.100 & 0.47 & 0.038 & 0.085 & 0.45 \\
\hline Age5 & -0.150 & 0.079 & -1.51 & $-10 \equiv$ & 0.074 & -1.44 \\
\hline Alone & -0.039 & 0.083 & -0.45 & - 53 & 0.0818 & 1.04 \\
\hline Control for SRHS & $-0.037 *$ & 0.015 & -2.49 & - & - & - \\
\hline Hausman-WuTest & 0.141 & & & - & & \\
\hline Pseudo $\mathrm{R}^{2}$ & 0.30 & & & 0.11 & & \\
\hline LR Test (all coeff. $=0$ ) & 39.13 & & & 28.04 & & \\
\hline
\end{tabular}

Note: SRHS means self-reporting housing satisfaction regarding the own dwelling; M.E indicates Marginal Effects. The omitted categories were: age group 55-59; professional and university education, dwelling size perceived as medium. Variance inflation factors (VIF) do not suggest the presence of multicollinearity, VIF equals 2.15 and VIF for SRHS equals 1.36 . *significant at 5\%; ** significant at $1 \%$.

housing environment. Importantly, it was found that when housing satisfaction was excluded from the equation, the explanatory power of the estimates was reduced by twothirds, while, regardless of the equation, WTS was not determined by an individual's housing wealth but by housing environmental characteristics. This might indicate that in their current homes people are already suffering certain inconveniences, and expect them to grow in the future. On the other hand, it could reflect the presence of alternative ways of paying for old-age dependency, including state-funded care or financial instruments such as home reversion.

\section{Willingness to Take Out Home Reversion}

Table 3 displays the level of familiarity with reverse mortgages (contracted jointly with an annuity) for a sample of older Spanish homeowners (i.e. the FAM covariate). Strikingly, the data indicate that 43 per cent of the overall reference population claimed to have heard of these financial products, this proportion being higher among men than among women (48 vs. 39 per cent, respectively). Although this level of awareness is lower than the levels reported, for example, by two US nationwide surveys of consumers aged 45 and over conducted by the AARP (51 per cent in 1999 and 70 per cent in 2007) and discussed in Redfoot et al. (2007), it can be deemed significant for two main reasons: first, today reverse mortgages are a relatively new financial instrument with a highly limited market 
Table 3. Familiarity with reverse mortgages

\begin{tabular}{lcccccccccc}
\hline & & & & & & & Age & Age & Age & Age \\
Overall & Men & Women & $\begin{array}{c}\text { Second. } \\
\text { educ. }\end{array}$ & $\begin{array}{c}\text { Univers. } \\
\text { educ. }\end{array}$ & $\begin{array}{c}\text { group } \\
\text { educ. }\end{array}$ & $\begin{array}{c}\text { group } \\
\text { group }\end{array}$ & $\begin{array}{c}\text { group } \\
60-69\end{array}$ & $\begin{array}{l}70-79 \\
80+\end{array}$ \\
\hline YES & $43 \%$ & $48 \%$ & $39 \%$ & $38 \%$ & $47 \%$ & $65 \%$ & $40 \%$ & $54 \%$ & $38 \%$ & $27 \%$ \\
NO & $57 \%$ & $51 \%$ & $61 \%$ & $62 \%$ & $53 \%$ & $35 \%$ & $60 \%$ & $46 \%$ & $62 \%$ & $73 \%$ \\
\hline
\end{tabular}

Note: Low level of education corresponds to primary and less than primary studies.

Source: Costa-Font, Gil \& Mascarilla (2007).

development and tradition in Spain; and, second, the existence of what is, in general, a poor financial culture in Southern Europe and, in particular, a low degree of interest among the elderly to contract financial products for their old age.

As expected, the data showed that this familiarity with respect reverse mortgages varied according to the level of education, ranging from a high level of awareness (65 per cent) among those with university education to a low level (38 per cent) among those with primary or less than primary studies. However, basic awareness seemed to show a nonlinear relation with age since those who were most aware (54 per cent) were individuals aged 60 to 69 years. ${ }^{19}$ Unfortunately, awareness does not necessarily mean that individuals understand the product or have a favourable opinion of or interest in reverse mortgages (Harris Interactive, 2007; Redfoot et al., 2007).

The survey also included a question to assess the circumstances under which individuals would be inclined to contract reverse mortgage products with a financial institution. The data showed a strong polarisation of responses: while 44 per cent of the sample stated they would be willing to contract reverse mortgages jointly with an annuity, another 45 per cent declared that they would never contract such equity conversion loans (Figure 3). Interestingly, among those who expressed an interest in contracting such loans, the most significant reason for doing so was the prospect of facing future economic difficulties as they sought to finance basic needs (37 per cent). Much less relevant were the motives to help other family members ( 5 per cent) or to finance higher levels of consumption ( 2 per cent). Although not reported, the data presented a clear pattern by educational attainment and age: among those with university studies, 67 per cent declared an interest for contracting reverse mortgages, while this proportion fell to just 33 per cent among those with low educational attainment. Similarly, approximately 50 per cent of individuals interviewed aged 65 and over claimed they would never contract a reverse mortgage, while this proportion was just 38 per cent for those aged 50 to 64 years old.

However, the results here differed significantly from those reported by Redfoot et al. (2007). These authors, working with a sample of US borrowers and non-borrowers of reverse mortgages, found a more similar proportion of respondents being driven by 'having more money to pay for basic needs' (48 per cent) and by 'having more money to spend on extras or quality of life' (38 per cent) when examining reverse mortgages, although this mix of reasons did vary by gender, age, health status, income and property value. Ultimately, the results seem to point to the existence of a strong, deeply-rooted culture in Spain of leaving bequests in favour of one's heirs. The most highly valued option for individuals is to retain their assets (as a 'reserve value', in exchange for care from children or for altruistic motives) and to leave them to their descendents, and only to contract reverse mortgage loans, sell or rent the house or other properties when facing 


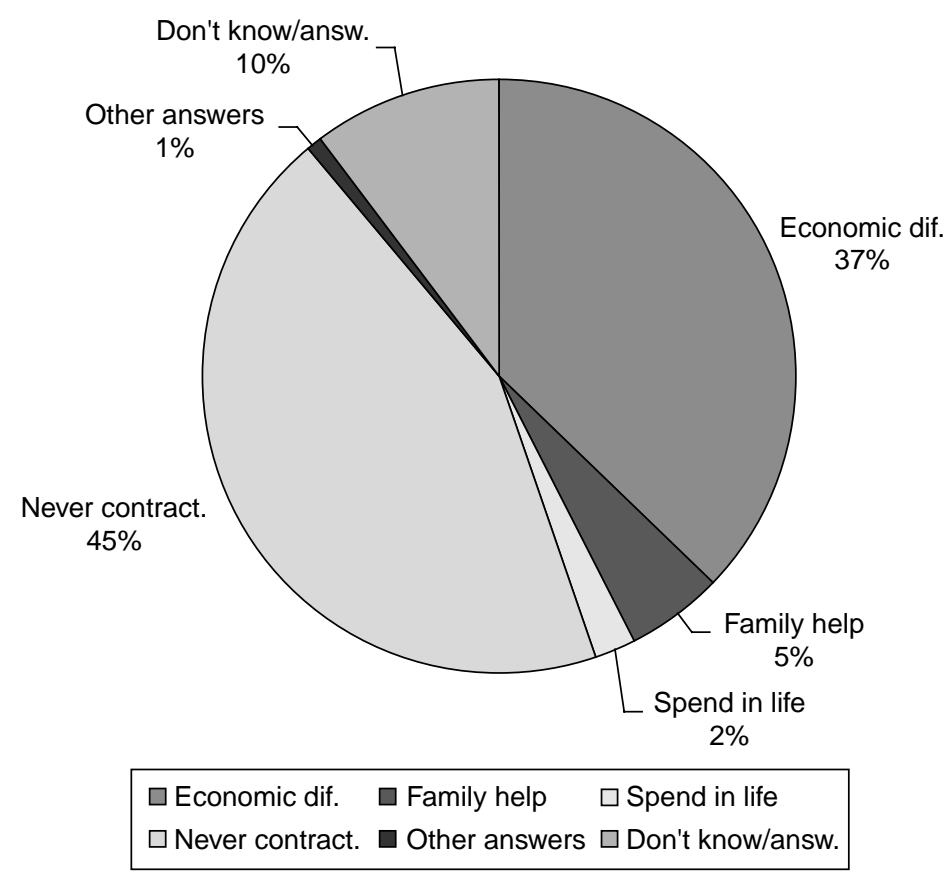

Figure 3. Motives for contracting reverse mortgages. Source: Costa-Font, Gil \& Mascarilla (2007).

future adverse economic circumstances. In other words, the preference for leaving a bequest or not contracting a reverse mortgage is contingent upon one's life cycle stage.

Table 4 presents the estimates for the bivariate probit regression framework. As cited above, there are two jointly estimated probability equations: equation 1 refers to the willingness to contract reverse mortgages (WTC) and equation 2 refers to the probability of being familiar with reverse mortgages (FAM). Note that coefficients in Table 4 can only be given a qualitative interpretation since they are not expressed in natural units. Moreover, to avoid potential problems of multicollinearity between income and education two separated models were specified. In both models, the estimate of the correlation coefficient for the two errors terms $(\rho)$ was positive $(0.41$ and 0.37 , respectively) and statistical significant according to the Wald test. This evidence indicated that unobservable factors that were positively related to reporting familiarity with reverse mortgages were positively related to the willingness of contracting such loans. Interestingly, the coefficient estimates of the two equations for both models were broadly similar to those obtained using binary probit regression models.

With regard to the WTC, the findings showed that women were more likely to take out a reverse mortgage than were men. The data also indicated a significant decreasing age effect as younger homeowners were more favourable to taking out home equity conversion loans. Interestingly, the results from model 1 indicated a positive and statistically significant effect of pension benefits on the willingness to contract a reverse mortgage. Similarly, the estimation of equation 2 demonstrated a positive and increasing effect of education on the willingness to contract such products: the higher the attainment in education the greater was the inclination to acquire reverse mortgages. Strikingly, according to the data, home 
Table 4. Determinants of the willingness to contract (WTC) and familiarity (FM) with reverse mortgages

\begin{tabular}{|c|c|c|c|c|c|c|}
\hline \multirow[b]{2}{*}{ WTC } & \multicolumn{3}{|c|}{ Model 1} & \multicolumn{3}{|c|}{ Model 2} \\
\hline & Coeff. & Robust s.e & t-value & Coeff. & Robust s.e & $\mathrm{t}$-value \\
\hline Home value & 0.054 & 0.117 & 0.46 & -0.040 & 0.106 & -0.37 \\
\hline Gender & $-0.302 *$ & 0.176 & -1.71 & $-0.263 *$ & 0.149 & -1.76 \\
\hline Age 1 & $0.994 * * *$ & 0.336 & 2.94 & $0.953 * * *$ & 0.306 & 3.11 \\
\hline Age 2 & $0.925 * * *$ & 0.316 & 2.92 & $0.973 * * *$ & 0.287 & 3.39 \\
\hline Age 3 & $0.743 * *$ & 0.328 & 2.27 & $0.722 * *$ & 0.296 & 2.44 \\
\hline Region 1 & 0.002 & 0.229 & 0.01 & 0.244 & 0.215 & 1.13 \\
\hline Region 2 & -0.174 & 0.251 & -0.69 & -0.051 & 0.244 & -0.21 \\
\hline Region 4 & -0.150 & 0.223 & -0.67 & -0.095 & 0.211 & -0.45 \\
\hline Region 5 & 0.055 & 0.273 & 0.20 & 0.046 & 0.251 & 0.18 \\
\hline Region 6 & -0.358 & 0.271 & -1.32 & -0.124 & 0.241 & -0.51 \\
\hline Region 7 & -0.370 & 0.447 & -0.83 & -0.318 & 0.410 & -0.77 \\
\hline Income & $0.309 * *$ & 0.157 & 1.97 & - & - & - \\
\hline Educ2 & - & - & - & $0.308 *$ & 0.170 & 1.82 \\
\hline Educ3 & - & - & - & $0.790 * * *$ & 0.211 & 3.74 \\
\hline Employed & 0.022 & 0.204 & 0.11 & -0.068 & 0.192 & -0.35 \\
\hline Inactive & 0.333 & 0.204 & 1.63 & 0.236 & 0.184 & 1.29 \\
\hline Constant & $-3.385 * *$ & 1.487 & -2.28 & -0.519 & 1.310 & -0.40 \\
\hline \multicolumn{7}{|l|}{ FAM } \\
\hline Home value & 0.013 & 0.117 & 0.11 & 0.023 & 0.109 & 0.21 \\
\hline Gender & -0.205 & 0.177 & -1.16 & 0.027 & 0.149 & 0.18 \\
\hline Age 1 & 0.286 & 0.338 & 0.84 & 0.112 & 0.292 & 0.39 \\
\hline Age 2 & $0.704 * *$ & 0.317 & 2.22 & $0.620 * *$ & 0.269 & 2.30 \\
\hline Age 3 & 0.334 & 0.330 & 1.01 & 0.251 & 0.281 & 0.89 \\
\hline Region 1 & 0.243 & 0.239 & 1.02 & 0.228 & 0.212 & 1.08 \\
\hline Region 2 & -0.250 & 0.261 & -0.95 & -0.225 & 0.246 & -0.91 \\
\hline Region 4 & 0.180 & 0.236 & 0.76 & 0.058 & 0.211 & 0.27 \\
\hline Region 5 & -0.044 & 0.282 & -0.16 & -0.107 & 0.252 & -0.43 \\
\hline Region 6 & 0.143 & 0.267 & 0.54 & 0.248 & 0.239 & 1.04 \\
\hline Region 7 & 0.356 & 0.436 & 0.82 & 0.221 & 0.396 & 0.56 \\
\hline Income & $0.552 * * *$ & 0.158 & 3.48 & - & - & - \\
\hline Educ2 & - & - & - & 0.202 & 0.168 & 1.20 \\
\hline Educ3 & - & - & - & $0.640 * * *$ & 0.207 & 3.09 \\
\hline Employed & 0.160 & 0.203 & 0.79 & 0.092 & 0.189 & 0.49 \\
\hline Inactive & -0.088 & 0.207 & -0.42 & -0.084 & 0.185 & -0.45 \\
\hline Constant & $-4.288 * * *$ & 1.549 & -2.77 & -0.911 & 1.340 & -0.68 \\
\hline$\rho-$ value & 0.410 & 0.078 & & 0.366 & 0.074 & \\
\hline No. of obs. & 353 & & & 413 & & \\
\hline Wald test $(\rho=0)$ & 21.80 & & & 20.45 & & \\
\hline
\end{tabular}

Note: WTC means willingness to contract reverse mortgages, while FAM expresses familiarity with reverse mortgages. The omitted categories are: female, age group 80 years and over, from the Region 3 , with primary or less than primary education and pensioner. Coefficients statistical significant at $* * * 1 \%$, $* * 5 \%$ and $* 10 \%$.

equity did not have an impact on the willingness to contract reverse mortgages. The results of the second equation also showed that only individuals aged between 60 and 69 years of age, and therefore near the normal retirement age in Spain, were aware of the existence of reverse 
mortgages (Hypothesis 2). As expected, pension benefit income and level of education positively influenced this level of awareness.

\section{Conclusions}

This paper has examined a set of hypotheses revolving around whether an individual's income/wealth determines his or her willingness-to-sell (WTS) their housing property to finance their old-age care. The paper has also examined the determinants of an individual's willingness to contract (WTC) certain financial instruments that provide liquidity (reverse mortgages) to cover the financial expenditures of old-age care. To do so, evidence has been drawn from two databases from Spain, a country where there is evidence of increasing awareness of the population ageing and the limited coverage of old age need.

The findings regarding the determinants of an individual's WTS their property to finance old age dependency needs (i.e. to buy an adequate house/flat or to pay for longterm care services), confirm the hypothesis of some environmental embededness whereby WTS a person's housing property is affected by a preference for 'ageing in place', rather than being the sole result of investment considerations. The results here confirm that housing satisfaction and housing characteristics together with health needs negatively determine WTS. However, neither housing value nor income appears to be significant determinants. Given that 'ageing in place' could be financed through a variety of instruments including equity release and home reversion, this study looks at a second hypothesis concerning the influence of income/wealth in determining the WTC home reversion loans. The latter was undertaken having first accounted for product knowledge, since only 43 per cent of the sample had any knowledge of home reversion. Our findings indicate that home reversion is seen as a second best option, to be adopted when an individual faces financial difficulties (liquidity constraints), although it was not reported as being dependent on (as being a substitute for) an individual's housing wealth. In Spain many older adults who own their dwelling are income poor, and fit in the so-called 'cashpoor and house-rich'. The findings show that a reverse mortgage contract is a suitable financial arrangement for this group of older adults. Results suggest that the reverse mortgage may be another feasible option to secure the retirement income for the next cohort of older adults in the coming decades. Our findings suggest that current income, education level, gender and age are the main determinants of home reversion loan uptake. One explanation for this finding is that Spanish society remains deeply entrenched in an inheritance culture where less affluent individuals would be unwilling to take out a reverse mortgage even when faced with economic difficulties.

Among the potential caveats of this study's findings lies the fact that panel data were not available so that the longitudinal perspective is missed. Evidence on adaptation to adverse environments can result in people accepting given circumstances (Elster, 1982; Sen, 1999), hence preferences might reflect some status quo bias, which means that results should be viewed with some caution. Therefore, future evidence from longitudinal studies will be an important research advancement for these caveats to be clarified.

If the scenario of an ageing population under financial strain becomes a reality and the findings here remain valid over time, then reverse mortgage plans should be seriously considered by the government or local banks so that alternative ways of financial support could be provided without expanding the financial burden on the government. However, whether reverse mortgages impact on poverty among the old-age population is still a 
question to be answered in future studies. Future studies should estimate the potential demand for reverse mortgages alongside other government interventions to alleviate poverty among older people.

\section{Notes}

${ }^{1}$ It appears that the elderly are more likely to have paid off their home mortgages when they own a property and, thus, can avoid the stressful effects of mortgage payments.

2 Ownership itself has been found to have positive effects on individual satisfaction, through greater self-esteem and improved health (Rohe et al., 2001), which in turn leads to very positive social consequences (e.g. lower crime).

${ }^{3}$ Indeed, the financial market has developed a range of instruments such as reverse mortgages, housing leasing and housing credits to make it easier to draw on housing wealth or to convert it into a more liquid form.

${ }^{4}$ See http://www2.vrom.nl/Docs/internationaal/housingStats2002.pdf

${ }^{5}$ On the other hand, they are less flexible mechanisms and rely on a set of contract conditions that individuals might not necessarily trust.

${ }^{6}$ Socio-demographic characteristics of interviewed individuals (i.e. gender, age, civil status and level of education) were similar to the figures of the same population groups at the national level. See Elvira et al. (2005) for a more comprehensive description of this database.

${ }^{7}$ Concretely, the survey question for WTS is: 'If in the future you suffer from a disability or chronic impairment that prevents you from carrying out some of the basic activities of daily living, would you be willing to sell your house/flat to access more suitable housing for your condition? (for example, to buy an adequate house/flat, to pay for a nursing home ... )'. On the other hand, residential preferences in case of old-age dependency are measured through the question: 'If in the future you have difficulty walking, bathing, phoning, taking medication etc., where would you like to live? (nursing home, live at home, relative's home)'.

${ }^{8}$ Note that the average family size in Spain is 2.9 members.

9 Self-reported housing satisfaction (SRHS) is measured using a scale ranging from 0 (unsatisfied) to 10 (totally satisfied).

${ }^{10}$ Most educated respondents expressed a higher preference for a nursing home (19.8 per cent).

11 The survey was conducted by an independent research company in April 2006.

12 For example, among others, Case \& Schnare (1994), Chian \& Tsui (2005), Hancock (1998), Kutty (1998, 1999), Mayer \& Simons (1994), Merill et al. (1994), Mitchell \& Piggott (2004), Ong (2008), Rasmussen et al. (1995) and Venti \& Wise (1991).

13 The Spanish Observatory of Old Age (IMSERSO, 2002) estimates that, in Spain, there are 240000 institutional beds and that approximately 3 per cent of the elderly are in institutional care, although this figure is four times higher for those aged 80 and over.

14 Ordered probit models were an alternative specification; however, the marginal effects for each change in the relevant coefficient were less straightforward to interpret and did not provide specific improvements to the explanatory power of the model reported here.

15 Again, WTC is observed by the researcher as a binary variable ( 1 if the individual is willing to contract a reverse mortgage, 0 otherwise). Similarly, the FAM variable is also a binary covariate ( 1 if the individual knows such financial conversion loans; 0 otherwise).

16 An interval regression model was adjusted to derive a continuous measure of net monthly benefit income, which was performed by adjusting a set of covariates (i.e. gender, age, civil status, education and size of the town). The results were approximately the same when pension income was input as a midpoint interval value.

17 The FAM covariate was calculated from the question: 'Have you ever heard of a reverse mortgage (jointly with an annuity) before?'. This question was accompanied by a previous short introduction of the type: 'if you are 70 years old and own a home, a financial institution pays you a monthly amount of money until your death and your heirs can recover the property if they repay the amount just borrowed'.

18 Note that Marginal Effects coefficients in Table 2 have a quantitative interpretation as they are measured in units of probability. For example the coefficient on gender in Equation (1) ( -0.128$)$ tells us that the probability of WTS the own home is 13 per cent lower for male individuals. 
19 Although not shown, the data pointed to the existence of a regional disparity in the level of familiarity with reverse mortgages with a better knowledge in the Autonomous Communities of Catalonia, Madrid, the Basque Country and the Balearic Islands.

\section{References}

Becker, G. S. (1981) A Treatise on the Family (Cambridge, MA: Harvard University Press).

Carreras, M., Mascarilla, O. \& Yegorov, Y. (2004) The evolution and the relationship of housing price and rental price in Barcelona 1970-2002, European Journal of Housing Policy, 4(1), pp. 19-56.

Case, B. \& Schnare, A. B. (1994) Preliminary evaluation of the HECM reverse mortgage program, Journal of the American Real State and Urban Economics Association, 22(2), pp. 301-346.

Castles, F. G. (1997) The really big trade-off: home ownership and the welfare state in the new world and the old, Acta Politica, 32, pp. 5-19.

Castles, F. G. \& Ferrera, M. (1996) Home ownership and the welfare state: is Southern Europe different? South European Society and Politics, 1, pp. 163-185.

Chian, N. C. \& Tsui, A. K. (2005) Reverse mortgages as retirement financing instrument: an option for 'asset-rich and cash-poor'. Singaporeans. SCAPE Working Papers Series No. 2005/03.

Costa-Font, J., Elvira, D. \& Mascarilla, O. (2006) Means testing and the heterogeneity of housing assets: funding long-term care in Spain, Social Policy \& Administration, 40(5), pp. 543-559.

Costa-Font, J., Gil, J. \& Mascarilla, O. (2007) Capacidad de la vivienda en propiedad como instrumento de financiación de las personas mayores en España (Barcelona: Fundación Edad \& Vida).

Costa-Font, J., Elvira, D. \& Mascarilla, O. (2009) 'Ageing in place'? Exploring elderly people's housing preferences in Spain, Urban Studies, 46(2), pp. 295-316.

Diaz, L. \& Stoyanova, A. (2008) The causal relationship between individual's choice behaviour and self-reported satisfaction: the case of residential mobility in the EU. XREAP2008-2 Working Papers.

Dorvil, H., Morin, P., Beaulieu, A. \& Robert, D. (2005) Housing as a social integration factor for people classified as mentally ill, Housing Studies, 20(3), pp. 497-519.

Elster, J (1982) Sour grapes-utilitarianism and the genesis of wants, in: A. Sen \& B. Williams (Eds) Utilitarianism and Beyond (Cambridge: Cambridge University Press).

Elvira, D., Rodriguez, P. \& Tomas, Z. (2005) Donde y Como Prefieren Vivir los Mayores de Hoy y Mañana en España (Barcelona: Fundación Edad \& Vida).

Ford, J., Burrows, R. \& Nettleton, S. (2001) Home Ownership in a Risk Society: A Social Analysis of Mortgage Areas and Possessions (Bristol: Polity Press).

Forrest, R., Murie, A. \& Williams, P. (1990) Home Ownership: Differentiation and Fragmentation (London: Unwin Hyman).

Gale, W. G. \& Pence, K. M. (2006) Are successive generations getting wealthier, and if so, why? Evidence from the 1990s, Brookings Papers on Economic Activity, 1, pp. 155-234.

Gilman, C. (2002) The Home: its Work and Influence (London: Alta Mira Press).

Hancock, R. (1998) Housing wealth, income and financial wealth of older people in Britain, Ageing and Society, $18(1)$, pp. 5-33.

Harris Interactive (2007) Two-thirds of US adults believe current mortgage product advertising and marketing lacks credibility. Harris Poll ${ }^{\circledR}$ No. 70, 16 July.

Hwang, S., Fuller-Thomson, J. D., Bryant, T., Habib, W. \& Regoeczi, W. (1999) Housing and Population Health: A Review of the Literature (Ottawa: Mortgage and Housing Corporation).

INE (Instituto de Estadística) (2004) Encuesta Continua de Presupuestos Familiares 2004 (Madrid: Instituto Nacional de Estadística).

IMSERSO (Instituto de Mayores y Servicios Sociales) (2002) Las Personas Mayores en España. Informe 2002 (Madrid: Ministerio de Trabajo y Asuntos Sociales).

IMSERSO (Instituto de Mayores y Servicios Sociales) (2006) Las Personas Mayores en España. Informe 2006. Datos Estadísticos Estatales y por Comunidades Autónomas (Madrid: Ministerio de Trabajo y Asuntos Sociales).

Jones, L. D. (1997) Testing the central prediction of housing tenure transition models, Journal of Urban Economics, 38(1), pp. 50-73.

Kee-Lee, C., Nelson, C. \& Iris, C. (2006) Willingness to consider applying for reverse mortgage in Hong Kong Chinese middle-aged homeowners, Habitat International, 30, pp. 716-727. 
Kutty, N. K. (1998) The scope for poverty alleviation among elderly home-owners in the United States through reverse mortgages, Urban Studies, 35(1), pp. 113-129.

Kutty, N. K. (1999) Demographic profiles of elderly homeowners in poverty who can gain from reverse mortgages. SSRN Working Paper.

Leviton, R. (2001) Reverse mortgage decision-making, Journal of Aging and Social Policy, 13, pp. 1-16.

Lewin, F. A. (2001) The meaning of home among elderly immigrants: the directions for future research and theoretical development, Housing Studies, 16(3), pp. 353-370.

Mayer, C. J. \& Simons, K. V. (1994) Reverse mortgages and the liquidity of housing wealth, Journal of the American Real Estate and Urban Economics Association, 22(2), pp. 235-255.

Merrill, S. R., Finkel, M. \& Kutty, N. K. (1994) Potential beneficiaries from reverse mortgage products for elderly homeowners: an analysis of AHS data, Journal of the American Real Estate and Urban Economics Association, 22(2), pp. 257-299.

Mitchell, O. \& Piggott, J. (2004) Unlocking housing equity in Japan, Journal of the Japanese and International Economies, 8(4), pp. 466-505.

Ong, R. (2008) Unlocking house equity through reverse mortgages: the case of elderly homeowners in Australia, The European Journal of Housing Policy, 8(1), pp. 61-79.

Rasmussen, D. W., Megbolugbe, I. F. \& Morgan, B. A. (1995) Using the 1990 public use microdata sample to estimate potential demand for reverse mortgage products, Journal of Housing Research, 6(1), pp. 1-23.

Redfoot, D. L., Scholen, K. \& Brown, S. K. (2007) Reverse Mortgages: Niche Product or Mainstream Solution? Report on the 2006 AARP National Survey of Reverse Mortgages Shoppers, AARP WP No. 2007-22.

Rohe, W. M. \& Stegman, M. A. (1996) The impacts of home ownership on the self-esteem, perceived control and life satisfaction of low-income people, Journal of American Planning Association, 60, pp. 37-81.

Rohe, W. M., Van Zandt, S. \& McCarthy, G. (2001) The social benefits and costs of homeownership: a critical assessment of the research. Low Income Homeownership Working Paper Series, Joint Center for Housing Studies, Harvard University.

Saunders, P. (1990) A Nation of Home Owners (London: Unwin Hyman).

Sen, A. (1999) Development as Freedom (Oxford: Oxford University Press).

Venti, S. F. \& Wise, D. A. (1989) Ageing, moving and housing wealth, in: D. Wise (Ed.) The Economics of Ageing (Chicago, IL: University of Chicago Press).

Venti, S. F. \& Wise, D. A. (1991) Ageing and the income value of housing wealth, Journal of Public Economics, 44(3), pp. 371-397. 


\section{Appendix}

Table A1. Average estimated price of housing per square metre (by Autonomous Region)

\begin{tabular}{lr}
\hline Autonomous Region & Price $(€)$ per $\mathrm{m}^{2}$ \\
\hline Andalusia & 1099 \\
Aragon & 1168 \\
Asturias & 1158 \\
Baleares & 1763 \\
The Canaries & 1348 \\
Cantabria & 1409 \\
Castile and Leon & 1110 \\
Castile-La Mancha & 810 \\
Catalonia & 1867 \\
Valencia & 1054 \\
Extremadura & 625 \\
Galicia & 878 \\
Madrid & 2485 \\
Murcia & 914 \\
The Basque Country & 2174 \\
Navarre & 1543 \\
La Rioja & 1283 \\
\hline
\end{tabular}

Source: EFECOM (2003)

Table A2. Descriptive statistics of the dataset on willingness-to-sell

\begin{tabular}{|c|c|c|c|c|}
\hline Variable & Definition & Type & Mean & s.e \\
\hline \multicolumn{5}{|c|}{ Dependent variable: } \\
\hline WTS & Willingness to sell dwelling & Dummy & 0.262 & 0.016 \\
\hline \multicolumn{5}{|c|}{ Explanatory variables: } \\
\hline \multicolumn{5}{|c|}{ Housing characteristics } \\
\hline SRHS & Self-reported housing satisfaction & Numeric & 7.909 & 0.066 \\
\hline Owner & Homeowner & Dummy & 0.838 & 0.014 \\
\hline House & Living in a house & Dummy & 0.151 & 0.013 \\
\hline Large size & Dwelling size perceived as large & Dummy & 0.408 & 0.018 \\
\hline Medium size & Dwelling size perceived as medium & Dummy & 0.471 & 0.019 \\
\hline Small size & Dwelling size perceived as small & Dummy & 0.122 & 0.006 \\
\hline \multicolumn{5}{|c|}{ Socio-economic determinants } \\
\hline Home value & House price $(€)$ & Numeric & 125,212 & 4388 \\
\hline Income & Income (logs) & Numeric & 10.252 & 0.158 \\
\hline Savings & Respondents reported capacity to save & Dummy & 0.412 & 0.018 \\
\hline Educ1 & No studies & Dummy & 0.032 & 0.007 \\
\hline Educ2 & Primary & Dummy & 0.141 & 0.013 \\
\hline Educ3 & Secondary & Dummy & 0.436 & 0.018 \\
\hline Educ4 & Pre-university and professional & Dummy & 0.154 & 0.013 \\
\hline Educ5 & Professional and university education & Dummy & 0.267 & 0.018 \\
\hline \multicolumn{5}{|c|}{ Individual characteristics } \\
\hline Gender & Male & Dummy & 0.346 & 0.018 \\
\hline Age1 & Age group 55-59 years old & Dummy & 0.281 & 0.016 \\
\hline Age2 & Age group 60-65 years old & Dummy & 0.176 & 0.014 \\
\hline Age3 & Age group $66-70$ years old & Dummy & 0.198 & 0.015 \\
\hline Age4 & Age group $71-80$ years old & Dummy & 0.124 & 0.012 \\
\hline Age 5 & Age group over 80 years old & Dummy & 0.113 & 0.012 \\
\hline Alone & Living alone & Dummy & 0.205 & 0.015 \\
\hline
\end{tabular}

Source: Encuesta Edad \&Vida (2003) 


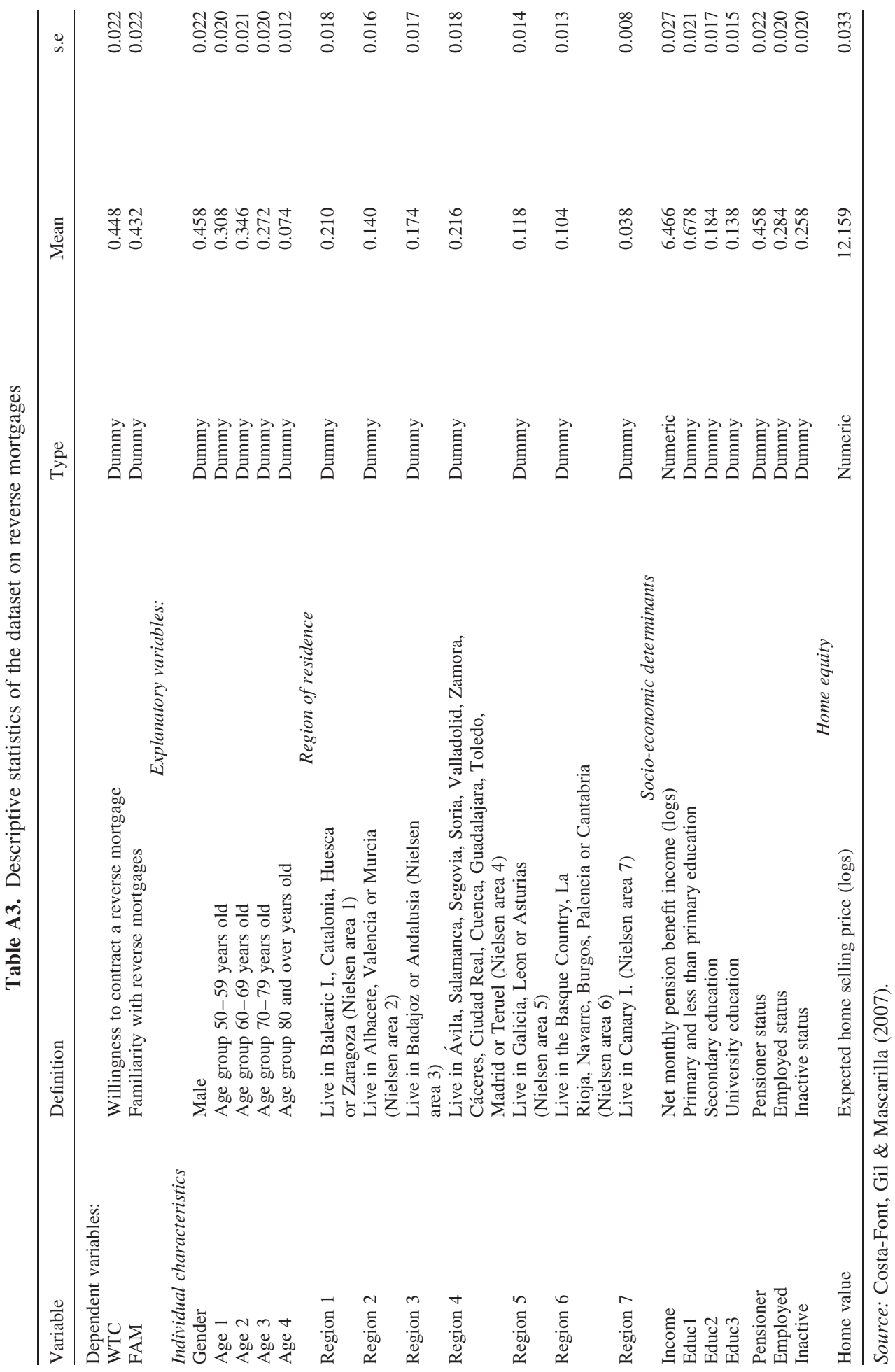

